\title{
DETERMINING THE PLANTING DATES OF POTATO VARIETIES IN THE EXTREME AGRO-CLIMATIC CONDITIONS OF KARAKALPAKSTAN
}

\author{
Tureniyazova Saltanat Elmuratovna \\ Karakalpak State University, Professor Assistant, Nukus, Karakalpakstan, Uzbekistan
}

Article DOI: https://doi.org/10.36713/epra9365

DOI No: 10.36713/epra9365

\begin{abstract}
ANNOTATION
The article presents the results of research conducted in the extreme agro-climatic conditions of the Republic of Karakalpakstan, considering the degree of soil salinity, to determine the timing of planting early, and middle ripening varieties of potatoes. Optimal planting times were determined for experiments with early planting-5, and for medium-early planting-5 varieties.
\end{abstract}

KEYWORDS: Plant, variety, development, soil, salinity, tuber, stem root, stalk, yield, number of fruits, weight of fruits.

\section{INTRODUCTION}

Relevance of the topic: The territory of the Republic of Karakalpakstan is located in the northern part of Uzbekistan and is characterized by severe agro-climatic conditions, short vegetation period, extra-arid nature and varying degrees of salinity of the soil. To grow and achieve the expected yield of potato varieties in such agro-climatic conditions, it is required to make additions to agro-technical treatments, considering the different aspects of agrobiocenosis. First, it is necessary to select the correct sowing periods for potato varieties. The most pressing issue is the organization of agro-technical methods applied from seedling germination to the end of the vegetation period, depending on the specifics of the biotope.

This is because, according to researchers conducting research on potato cultivation, in many place, there are data confirming that the expected yield when planted in the agrobiocenosis of Karakalpakstan is not obtained from potato varieties $[1,2,3,4,5$, $6,7,8,9,10]$.

Therefore, in agrobiocenosis with such a difference, to get the expected yield by planting a variety of potato, it is necessary to correctly determine the planting dates of potato varieties proposed for planting in the early and early-medium periods and it is required to carry out agrotechnical methods correctly and based on scientific recommendations.

\section{RESEARCH OBJECTIVES AND METHODS}

Early ripening 5 and medium-early ripening 5 varieties of potatoes were taken as the object of research. Using methods proposed to use in the cultivation of potatoes by V.I.Zuev (2003). B.J.Azimov, B.B.Azimov (2006). T.E.Ostonaqulov et al. $(2006 ; 2007 ; 2008)$ to determine the sowing dates of potato varieties, placement of experimental schemes, statistical analysis was carried out based on the methods of B.A. Dospekhov (1985).

\section{RESULTS}

The main differences of the agro-climatic conditions of the Republic of Karakalpakstan are that in winter (December, January, February) the temperature drops to minus $15-20{ }^{\circ} \mathrm{C}$, the surface freezes, and it is observed that in March the temperature rises, in the second- and third-decades average temperature is known to rise to $+2 ;+10^{\circ} \mathrm{C}$. As a result, from the time of the temperature rise in the top layer of soil, the time when it is possible to sow crops is the third decade of March. 


\section{EPRA International Journal of Research and Development (IJRD)

Considering the fact that the seeds of the potato plant germinate when the soil temperature rises to $+5^{\circ} \mathrm{C}$, the sowing period is set from the third decade of March. The second term is determined to be the first decade of April and the third term is the second decade of April.

As a result, the research found that in 2019, the average air temperature in the third decade of March was $10.5^{\circ} \mathrm{C}$ In the first decade of April $12.8^{\circ} \mathrm{C}$, and in the second decade of the month $13.5^{\circ} \mathrm{C}$. Temperature changes were observed in 2020 at $9.8^{\circ} \mathrm{C}, 11.4^{\circ} \mathrm{C}, 15.0^{\circ} \mathrm{C}$, and in 2021 at $8.7^{\circ} \mathrm{C}$, $14.3^{\circ} \mathrm{C}, 18.3^{\circ} \mathrm{C}$.

Over the years, in an environment where the average temperature in April 2019 rose to $14.1^{\circ} \mathrm{C}$, in May $23.1^{\circ} \mathrm{C}$, in June $27.6^{\circ} \mathrm{C}$, in $2020-14.5^{\circ} \mathrm{C}$, $23.7^{\circ} \mathrm{C}, 27.6^{\circ} \mathrm{C}$, in $2021-13.2^{\circ} \mathrm{C}, 25.3^{\circ} \mathrm{C}, 29.1^{\circ} \mathrm{C}$, it was found that the potato varieties taken to research were planted, grown during the vegetation period and harvested.

The first sowing period of the potato varieties in the experimental fields was carried out on March 24, the second on April 5 and the third on April 14. The seeds were sown to a depth of $9-10 \mathrm{~cm}$ in a scheme $70 \times 25 \mathrm{~cm}$.

The results of the observations made during the growing season are given in Table 1. From this it can be seen that from the seeds sown in the third decade of March, when the average temperature is $8.7-10.5^{\circ} \mathrm{C}$, the seedlings germinate in 14-19 days and start to develop and grow fully. While the blooming period of varieties developed at this level was observed after 40-47 days, full fruit maturation, the duration of the ripening phase required 78-89 days, and the fruits in the experimental fields were dug because they ripened in 90-93 days.

In the analysis of the accumulated yield of potato varieties, in the years when spring came early, the fields planted in the third decade of March had a high yield. While in the years when spring came late the varieties sown in the first decade of April had a high yield.

Table 1.

Yield and possibilities of germination and blooming of potato varieties planted at different times

\begin{tabular}{|c|c|c|c|c|c|c|c|}
\hline \multirow[t]{2}{*}{ Varieties } & \multirow{2}{*}{$\begin{array}{c}\text { Seed } \\
\text { planting } \\
\text { date }\end{array}$} & \multicolumn{2}{|c|}{$\begin{array}{c}\text { Germination } \\
\text { phase }\end{array}$} & \multicolumn{2}{|c|}{ Flowering phase } & \multicolumn{2}{|c|}{$\begin{array}{l}\text { Harvested } \\
\text { yield, t/ha }\end{array}$} \\
\hline & & Date & Days & Date & Days & Total & Subtraction \\
\hline \multirow[t]{3}{*}{ Arnova } & 24.03. & 11.04. & 19 & 06.05 & 46 & 20.5 & 2.0 \\
\hline & 05.04. & 22.04. & 17 & 19.05. & 44 & 19.0 & 1.9 \\
\hline & 14.04. & 29.04 & 15 & 27.05 . & 43 & 18.5 & 0.6 \\
\hline \multirow[t]{3}{*}{ Sante } & 24.03. & 10.04 . & 18 & 09.05 & 47 & 18.6 & 0.1 \\
\hline & 05.04. & 21.04. & 16 & 20.05 . & 45 & 21.3 & 4.2 \\
\hline & 14.04. & 28.04 . & 14 & 26.05 . & 42 & 19.3 & 1.4 \\
\hline \multirow[t]{3}{*}{ Zarafshan } & 24.03. & 07.04. & 15 & 05.05 & 43 & 20.5 & 2.0 \\
\hline & 05.04 . & 22.04. & 17 & 19.05. & 44 & 19.6 & 2.5 \\
\hline & 14.04. & 02.05. & 18 & 27.05 . & 43 & 17.2 & -0.7 \\
\hline \multirow[t]{3}{*}{ Romana } & 24.03. & 12.04. & 18 & 06.05 & 44 & 19.3 & 0.8 \\
\hline & 05.04. & 19.04. & 14 & 17.05 . & 42 & 21.4 & 4.3 \\
\hline & 14.04. & 29.04. & 15 & 24.05 . & 40 & 18.6 & 0.7 \\
\hline \multirow[t]{3}{*}{ Umid } & 24.03. & 09.04. & 17 & 07.05 & 45 & 21.4 & 2.9 \\
\hline & 05.04. & 20.04 . & 15 & 18.05. & 43 & 22.3 & 5.2 \\
\hline & 14.04. & 30.04 & 16 & 28.05 . & 44 & 19.6 & 1.7 \\
\hline \multirow[t]{3}{*}{ Surkhan } & 24.03. & 11.04. & 19 & 08.05 & 46 & 15.3 & -3.2 \\
\hline & 05.04. & 20.04. & 15 & 16.05 . & 41 & 16.5 & -0.6 \\
\hline & 14.04. & 28.04 . & 14 & 24.05 . & 40 & 14.6 & -3.3 \\
\hline \multirow[t]{3}{*}{ Picasso } & 24.03. & 10.04. & 18 & 05.05 & 43 & 18.8 & 0.3 \\
\hline & 05.04. & 21.04. & 16 & 17.05 . & 42 & 19.8 & 2.7 \\
\hline & 14.04. & 28.04 . & 14 & 24.05 . & 40 & 17.3 & -0.6 \\
\hline \multirow{3}{*}{$\begin{array}{c}\text { Dosmpalek } \\
\text { (control) }\end{array}$} & 24.03. & 09.04. & 17 & 06.05 & 44 & 18.5 & - \\
\hline & 05.04. & 20.04. & 15 & 17.05. & 42 & 17.1 & - \\
\hline & 14.04. & 28.04 . & 14 & 27.05 . & 43 & 17.9 & - \\
\hline
\end{tabular}
$\mathbf{E K F}_{05}(\mathrm{t} / \mathrm{ha})$
$\mathbf{S}_{\mathbf{x}}$
$(\%)$
0.29 


\section{EPRA International Journal of Research and Development (IJRD)

Compared to the local Dosmpalek variety, the yield during the early planting period of Arnova was higher, and Sante, Zarafshan, Umid, and Picasso varieties yielded 2.7-4.2 tons more per hectare. It was found that the yield of Surkhan variety, as well as some varieties in the fields planted in the third period, was slightly lower.

\section{CONCLUSION}

Considering that in the soil and agroclimatic conditions of the northern and central regions of Karakalpakstan agrobiocenosis the air temperature creates favorable conditions for germination of potato seeds from the third decade of March, in the years when spring comes early it is recommended to sow early ripening varieties by the end of the month. In the years when spring comes late, in the first decade of April, when the seeds are fully sown and applied within the recommended agro-technical measures, it is possible to get a yield of 19.3-21.4 tons per hectare. To do this, it is necessary to select the spacing in the scheme $70 \times 25$ $\mathrm{cm}$, sow the seeds to a depth of 9-10 $\mathrm{cm}$ and apply agro-technical measures depending on the growth and development phases of the plant. Yield should be harvested in the specified method, depending on the variety, considering that the stalks are completely dry. That is, the seeds are fully mature in 90-93 days after sowing.

\section{REFERENCES}

1. Abdukarimov D.T. Early potatoes. Tashkent «MEHNAT» 1987. -91 p.

2. Azimov B.B. «Scientific substantiation of the technology of cultivation and storage of food and seed potatoes in the central zone of Uzbekistan» / Abstract of dissertation for the degree of Doctor of Agricultural Sciences.Tashkent, 2009-47 p.

3. Azimov B.J., Azimov B.B. Statistical analysis of experimental results. $T$., 2006.-5 $p$.

4. Dospekhov B.A. Methodology of field experiment "Kolos", M., 1985. 294 p.

5. Zuev V.I. Recommendations for the cultivation of potatoes on saline soils-T., MSVX 2003. -9 p.

6. Hakimov R.A., Abbozov A.M. Recommendations on recommended varieties and cultivation technologies of vegetable, melon and potato crops for Tashkent region.-T., 2006. -26 p.

7. Ostonakulov T.E., Usmonov N. Use of green manures in potato growing, Samarkand, 2006.$136 \mathrm{p}$.

8. Ostonakulov T.E., Otamurodov E.O. Potato growing in mountainous areas. -Tashkent, 2007.$112 p$.

9. Ostonakulov T.E., Hamzaev A.X. Scientific bases of potato growing in Uzbekistan.-Tashkent, "Fan", 2008.-443 p.

10. Ishimov S.X. Selection of varieties for growing potatoes in the south of Uzbekistan, determination of planting dates and depth.
Abstract of dissertation for the degree of Doctor of Agricultural Sciences. -T, 2011.- 24 p. 